\title{
ОБЯЗАТЕЛЬНЫЙ ПЛАТЕЖ И ДРУГИЕ НЕТИПИЧНЫЕ ТРЕБОВАНИЯ УПОЛНОМОЧЕННОГО ОРГАНА В ДЕЛАХ О БАНКРОТСТВЕ
}

\begin{abstract}
Аннотация. Закрепленное в статье 2 Закона о банкротстве понятие “обязательный платеж” нельзя признать исчерпывающим и раскрывающим все виды публичных требований в делах о банкротстве. В теории и на практике рассматриваемое понятие толкуется расширено, путем отождествления с обязательными платежами иных публичных платежей: исполнительский сбор, плата за негативное воздействие на окружающую среду и таможенные пошлины. Исследование категории обязательный платеж невозможно в отрыве от фигуры уполномоченного органа, обладающего исключительной компетенцией на представление в делах о банкротстве требований об уплате обязательных платежей. Однако уполномоченный орган представляет в делах о банкротстве не только обязательные платежи, но и иные публичные требования (например, требования о взыскании задолженности по государственному контракту). По этой причине необходимо определить границы между обязательными платежами и иными публичными требованиями. В основу работы положены методы индукции, дедукции, а также исторического и сравнительного (в том числе международного) правоведения. В исследовании выявлены противоречия в законодательстве и судебной практике по вопросам толкования понятия “обязательный платеж” и компетенции уполномоченного органа в делах о банкротстве. Особое внимание в статье уделено совершенствованию механизмов взыскания задолженности по публичным требованиям в делах о банкротстве. Автором исследованы иностранные научные публикации и сформулированы предложения по развитию института налогового залога в обеспечение требований, представляемых уполномоченным органом в Российской Федерации. В работе выработаны теоретические и практические предложения по решению проблем в сфере взаимодействия налогового законодательства и законодательства о банкротстве.
\end{abstract}

Ключевые слова: публичные требования, очередность удовлетворения требований, обязательный платеж, банкротство, несостоятельность, налоговые вопросы, исполнительский сбор, залог, уполномоченный орган, налоговый орган.

\begin{abstract}
According to the author of the article, the concept of 'obligatory payment' set forth by Article 2 of the Bankruptcy Law cannot be considered as complete and covering all kinds of public claims that may arise in the process of bankruptcy proceedings. In theory and practice the term is widely interpreted as other obligatory payments such as execution fee, pollution fee and customs duty. However, it is impossible to fully study the category of obligatory payment without considering an authorized authority having exclusive competence to impose obligatory payment requests in bankruptcy proceedings. Yet, such authorized authority usually imposes not only obligatory payments but also other public claims (for example, debt recovery under the government contract). For this reason, it is necessary to define borders between obligatory payments and other public claims. The research is based on the methods of induction, deduction as well as methods of historical and comparative (including international) law. In his research Izvekov describes contradictions in legal and judicial practice of interpretation the term 'obligatory payment' and competences of an authorized authority in bankruptcy proceedings. Special attention is paid to improving the mechanism of collecting debts under public claims in bankruptcy proceedings. The author also analyzes foreign publications and articles on the matter and makes his own suggestions on how to develop the institution of tax lien in order to ensure the compliance with the requirements imposed by such an authorized authority in the Russian Federation. The author of the article also provides theoretical and practical recommendations on how to solve relevant issues in the spheres of tax legislation and bankruptcy legislation.
\end{abstract}

Keywords: lien, performing collection, public requirements, priority of claims, obligatory payment, bankruptcy, insolvency, authorized authority, tax issues, tax authority. 


\section{Налоги и налогообложение 10(148) • 2016}

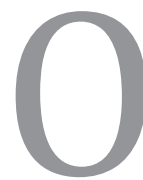

фициальное позитивное понятие обязательного платежа по делам о банкротстве закреплено в статье 2 Федерального закона от 26.10.2002 №127-Ф3 «0 несостоятельности (банкротстве)» [6] (далее - Закон о банкротстве). Обязательные платежи - налоги, сборы и иные обязательные взносы, уплачиваемые в бюджет соответствующего уровня бюджетной системы Российской Федерации и (или) государственные внебюджетные фонды в порядке и на условиях, которые определяются законодательством Российской Федерации, в том числе штрафы, пени и иные санкции за неисполнение или ненадлежащее исполнение обязанности по уплате налогов, сборов и иных обязательных взносов в бюджет соответствующего уровня бюджетной системы Российской Федерации и (или) государственные внебюджетные фонды, а также административные штрафы и установленные уголовным законодательством штрафы.

Рассматриваемое понятие нельзя признать исчерпывающим и раскрывающим все виды обязательных платежей.

Высшим Арбитражным судом РФ (далее - ВАС РФ) в Постановлении Пленума ВАС РФ от 23.07.2009 №59 «0 некоторых вопросах практики применения Федерального закона «Об исполнительном производстве» в случае возбуждения дела о банкротстве» расширено толкование рассматриваемого понятия, согласно которому исполнительский сбор также относится к обязательным платежам. Там же в пункте 17 указан специальный порядок удовлетворения требований, в основе которых исполнительский сбор (пункт 3 статьи 137 Закона о банкротстве).

А.Н. Борисов [21] признает недостаточность правого регулирования понятия «обязательный платеж» как в Федеральном законе от 08.01.1998 №6-Ф3 «О несостоятельности (банкротстве)» [7], так и в Законе о банкротстве 2002 года и говорит о плате за негативное воздействие на окружающую среду в качестве ещё одного вида обязательного платежа.

Не безызвестны правовые позиции, сформулированные Конституционным Судом Российской Федерации в Определении от 10.12.2002 №284-0 «По запросу Правительства Российской Федерации о проверке консти- туционности Постановления Правительства Российской Федерации «Об утверждении порядка определения платы и ее предельных размеров за загрязнение окружающей природной среды, размещение отходов, другие виды вредного воздействия» [20] и статьи 7 Федерального закона «0 введении в действие части первой Налогового кодекса Российской Федерации» [13], согласно которым платежи за негативное воздействие на окружающую среду являются обязательными публично-правовыми платежами (в рамках финансово-правовых отношений). Они носят индивидуально-возмездный и компенсационный характер и являются по своей правовой природе фискальным сбором. Минэкономразвития РФ письмом №Д06-2677 от 16.09.2009 разделяет позицию Конституционного Суда Российской Федерации.

С учетом изложенной позици и Конституционного Суда Российской Федерации, рассматриваемые платежи за негативное воздействие на окружающую среду также включаются в понятие обязательный платеж.

Кроме того, Законом о банкротстве прямо не называются еще одни обязательные платежи - таможенные пошлины - обязательный платеж, взимаемый таможенными органами в связи с перемещением товаров через таможенную границу (статья 4 Таможенного кодекса Таможенного союза [5]).

С. А. Викторов [23] расширительно толкует категорию «обязательный платеж», и заключает, что законодательное закрепление рассматриваемой категории вполне оправданно, поскольку и налоги (сборы), и взносы на обязательное социальное страхование, и плата за загрязнение окружающей природной среды, и плата за пользование водными объектами, и таможенные платежи обладают совокупностью общих признаков, позволяющих объединить их в единое целое (представляют собой изъятие государством у физических и юридических лиц части принадлежащего им на праве собственности имущества с целью обеспечения исполнения государством публично-правовых функций; уплата данных платежей обеспечена механизмом государственного принуждения, т.е. не зависит от воли (желания) хозяйствующих субъектов; основные элементы данных платежей (база для 


\section{Правовое регулирование налоговых отношений}

начисления, ставки, сроки уплаты и пр.) устанавливаются нормативно-правовыми актами и также не зависят от воли (желания) хозяйствующих субъектов).

Исследование категории обязательный платеж невозможно в отрыве от фигуры уполномоченного органа, обладающего исключительной компетенцией на представление в делах о банкротстве требований об уплате обязательных платежей. Однако уполномоченный орган представляет в делах о банкротстве не только обязательные платежи, но и иные публичные требования. По этой причине необходимо определить границы между обязательными платежами и иными публичными требованиями.

Закон о банкротстве раскрывает понятие уполномоченного органа через систему представляемых в деле о банкротстве требований, в основе которых лежат частные и публичные обязательства. Согласно статье 2 Закона о банкротстве уполномоченный орган - федеральный орган исполнительной власти, уполномоченный Правительством Российской Федерации на представление в деле о банкротстве и в процедурах, применяемых в деле о банкротстве, требований об уплате обязательных платежей и требований Российской Федерации по денежным обязательствам, а также органы исполнительной власти субъектов Российской Федерации, органы местного самоуправления, уполномоченные представлять в деле о банкротстве и в процедурах, применяемых в деле о банкротстве, требования по денежным обязательствам соответственно субъектов Российской Федерации, муниципальных образований.

\section{Исполнительный сбор как разновидность обязательного платежа в деле о банкротстве}

Как уже было указано исполнительский сбор относится к обязательным платежам по делам о банкротстве в силу разъяснений Высшего Арбитражного Суда РФ. До настоящего времени не выработано целостного представления о правовой природе исполнительского сбора в рамках процедуры банкротства, об отнесении данного обязательного платежа к текущим требованиям или подлежащим включению в реестр требований кредиторов.
Полагаем недопустимым отождествлять понятия «сбор»и «исполнительский сбор»в контексте статьи 2 Закона о банкротстве, так как конструкция указанной нормы отсылает в первую очередь к налогам, сборам и иным обязательным взносам в бюджет и внебюджетные фонды. То есть речь идет о платежах, возлагающих на должника обязательства, основанные на принципах всеобщности, равенства, недискриминации и экономической обоснованности. Правовая природа исполнительского сбора отличается и не предполагает соответствие указанным принципам. Также представляется необоснованным любое пересечение этих понятий как части и целого.

В соответствии со статьей 112 Федерального закона от 02.10.2007 №229-ФЗ «Об исполнительном производстве» [8], право судебного пристава-исполнителя на вынесение постановления о взыскании исполнительского сбора зависит от исполнения должником исполнительного документа, в частности от срока его исполнения.

Согласно позиции Конституционного Суда Российской Федерации, выраженной в Постановлении от 30.07.2001 №13-П [19], сумма исполнительского сбора относится к мерам принуждения в связи с несоблюдением законных требований государства. Судя по всему, данная мера представляет из себя штрафного санкцию, возлагающую на должника публично-правовую ответственность, в связи с совершенным правонарушением в рамках исполнительного производства.

Изложенная в Пост анов лени и Конституционного Суда Российской Федерации №13-П позиция имеет общий характер и являются обязательной для неопределенного круга лиц в силу статьи 6 Федерального конституционного закона от 21.07.1994 №1-ФКЗ «0 Конституционном Суде Российской Федерации» [1].

Содержание понятия «обязательный платеж» не охватывает соответствующую санкцию, говоря лишь о санкциях за нарушение обязательств по уплате налогов, сборов и иных обязательных взносов в бюджет и внебюджетные фонды. Поэтому, не смотря на семантическую близость рассматриваемых категорий, «сбор» и «исполнительский сбор»не пересекаются и 


\section{Налоги и налогообложение 10(148) • 2016}

не совпадают в диспозиции статьи 2 Закона о банкротстве.

Что касается квалификации в делах о банкротстве требований в основе которых лежит обязанность по уплате исполнительского сбора, приведенное разъяснение не устраняло существовавшую неопределенность до принятия Постановления Пленума ВАС РФ от 23.07.2009 №59.

Л.А. Деревягина [24], рассматривая соответствующие правоотношения с позиции Постановления №13-П, полагает, что исполнительский сбор не относится к денежным обязательствам и обязательным платежам, а представляет собой санкцию штрафного характера, мотивируя это тем, что размер задолженности по исполнительскому сбору суды не принимают во внимание при установлении признаков банкротства, определенных в статье 3 Закона о банкротстве.

В соответствии с абзацем 4 пункта 2 статьи 4 данного Закона о банкротстве подлежащие применению за неисполнение или ненадлежащее исполнение обязательства неустойки (штрафы, пени), проценты за просрочку платежа, убытки, подлежащие возмещению за неисполнение обязательства, а также иные имущественные и (или) финансовые санкции, в том числе за неисполнение обязанности по уплате обязательных платежей, не учитываются при определении признаков банкротства. Следует учесть, что с даты введения процедуры наблюдения приостанавливается исполнение исполнительных документов по имущественным взысканиям (пункт 1 статьи 63 Закона о банкротстве).

Право обращаться в арбитражный суд с требованиями о включении исполнительского сбора в реестр требований кредиторов предоставляется Федеральной налоговой службе России как уполномоченному органу в делах о банкротстве и в процедурах банкротства, действующему во исполнение Постановления Правительства РФ от 29.05.2004 №257 «Об обеспечении интересов Российской Федерации как кредитора в делах о банкротстве и в процедурах банкротства» [14].

Рассматривая соответствующие требования уполномоченного органа Пленум Высшего Арбитражного Суда РФ в Постановлении от 22.06.2006 №25 «0 некоторых вопросах, свя- занных с квалификацией и установлением требований по обязательным платежам, а также санкциям за публичные правонарушения в деле о банкротстве» указал, что для решения вопроса о включении в реестр и взыскании задолженности по исполнительскому сбору суду надлежит установить удовлетворены ли требования взыскателя по каждому из исполнительных документов (включены ли они в реестр требований кредиторов), неисполнение которых должником добровольно в установленный срок послужило основанием для вынесения судебным приставом-исполнителем постановлений о взыскании исполнительского сбора, а также не признаны ли недействительными постановления судебного пристава.

Приведенное разъяснение породило противоречивую судебную практику по вопросам о включении исполнительского сбора в реестр требований кредиторов. Первый подход проявился в отказе во включении в реестр требований кредиторов требований по исполнительскому сбору, если сумма основного обязательства не погашена в полном объеме (см., например, Постановление ФАС Северо-Кавказского округа от 18.02.2009 по делу №A15-1069/2006 (Определением ВАС РФ от 29.06.2009 №BAC-6291/09 отказано в передаче дела в Президиум ВАС РФ), Постановление ФАС Восточно-Сибирского округа от 24.10.2007 по делу №A74-4119/06-Ф02-7717/07, Постановление ФАС Западно-Сибирского округа от 26.11.2008 №Ф04-6968/2008(15863-А67-44)). Вторая позиция заключается в возможности включения в реестр требований кредиторов должника исполнительского сбора в случае предварительного включения в реестр требований сумм основного обязательства (см, например, Постановление ФАС Северо-Западного от 18.03.2009 по делу №A13-10126/2008, от 29.01.2009 по делу №A05$5454 / 2008$ и Постановление ФАС Волго-Вятского от 01.09.2008 по делу №A29-5827/2007, а также определения Арбитражного суда Оренбургской области от 04.12.2008 по делу №A47-760/2008, от 15.05.2009 по делу №A47-10941/2007, от 07.02.2008 по делу №А47-1146/2006, от 29.11.2008 по делу №A47-2667/2008).

В результате буквального прочтения мотивировочных частей выше указанных судебныхактов Л.А. Деревягина предлагает включать исполни- 


\section{Правовое регулирование налоговых отношений}

тельский сбор в реестр требований кредиторов, но оплачивать не в порядке очередности установленной Законом о банкротстве, а руководствуясь Законом об исполнительном производстве-после погашения сумм основного долга.

С такой позицией обосновано не соглашается К.Н. Иголкина, которая обосновывает специфику взыскания исполнительного сбора по исполнительному документу о взыскании текущих платежей в деле о банкротстве, единством судьбы основного денежного обязательства и названного сбора, а исполнительный сбор по исполнительному документу о взыскании долга наряду с самим обязательством относит к требованию, подлежащему включению в реестр требований кредиторов [25].

Вопрос об очередности исполнения обязательных платежей в делах о банкротстве неоднократно поднимался в научной литературе, в том числе автором настоящей работы [26, 27]. Однако целью настоящего исследования является не определение условий и порядка погашения требований по обязательным платежам, а выявление нетипичных требований, представляемых уполномоченным органом в делах о банкротстве.

Отсутствие позитивного закрепления в статье 2 Закона о банкротстве категории исполнительный сбор как разновидность обязательного платежа по делам о банкротстве, безусловно является упущением законодателя и требует совершенствования юридической техники.

\section{Платежи за негативное воздействие на окружающую среду как разновидность обязательного платежа в деле о банкротстве}

Отсутствие прямого указания в статье 2 Закона о банкротстве платежей за негативное воздействие на окружающую среду, не смотря на разъяснения Конституционного Суда РФ, сформировало неоднозначную судебную практику в вопросах включения сумм задолженности в реестр требований кредиторов и определении надлежащим образом уполномоченного органа, представляющего соответствующий публичный интерес в делах о банкротстве.

В соответствии с положениями федерального законодательства платежи за негативное воздействие носят индивидуально-возмездный и компенсационный характер и являются по своей правовой природе фискальным сбором обязательным платежом в бюджетную систему Российской Федерации.

Плата за негативное воздействие на окружающую среду отнесена в состав неналоговых доходов с нормативом отчислений (п. 1 ст. 51, ст. 57, 62 Бюджетного кодекса РФ [2]) в федеральный, региональный и местный бюджет.

В рамках выполнения возложенных законодательством на Ростехнадзор полномочий по администрированию платы за негативное воздействие на окружающую среду администраторы, назначенные в соответствии с приказом Ростехнадзора (территориальные органы Ростехнадзора и (или) подведомственные ему учреждения), обязаны осуществлять бюджетный учет по начислению и уплате обязательного платежа, контроль за правильностью исчисления, полнотой и своевременностью платежей в бюджет, в том числе в пределах своей компетенции взыскивать задолженности по платежам в бюджет [22].

Ростехнадзор является уполномоченным органом, осуществляющим на основании статьи 6 Бюджетного кодекса Российской Федерации и в соответствии с Постановлением Правительства Российской Федерации от 13.09.2010 №717 «О внесении изменений в некоторые Постановления Правительства Российской Федерации по вопросам полномочий Министерства природных ресурсов и экологии Российской Федерации, Федеральной службы по надзору в сфере природопользования и Федеральной службы по экологическому, технологическому и атомному надзору» [15], полномочия по надзору в сфере осуществления контроля и надзора за выбросами и сбросами загрязняющих веществ в окружающую среду (за исключением радиоактивных веществ), осуществления вредного физического воздействия на атмосферный воздух.

Согласно статье 1 Федерального закона от 10.01.2002 №7-Ф3 «Об охране окружающей среды» [9] (далее - Закон об охране окружающей среды) негативным воздействием на окружающую среду является воздействие хозяйственной и иной деятельности, последствия которой 


\section{Налоги и налогообложение 10(148) • 2016}

приводят к негативным изменениям качества окружающей среды.

В силу пункту 1 статьи 16 Закона об охране окружающей среды негативное воздействие на окружающую среду является платным.

Плата за негативное воздействие на окружающую среду является обязательным федеральным платежом, предназначенным для возмещения расходов и затрат публичной власти на охрану и восстановление окружающей среды.

Названные платежи взимаются с хозяйствующего субъекта во исполнение им финансово-правовых обязательств (обязанностей), возникающих из осуществления такой деятельности, которая оказывает негативное (вредное) воздействие на окружающую среду, и представляют собой форму возмещения экономического ущерба от такого воздействия.

Данные платежи носят компенсационный характер и устанавливаются на основе принципа эквивалентности, исходя из вида и объема негативного воздействия на окружающую среду (в пределах допустимых нормативов).

Плата за негативное воздействие на окружающую среду предусмотрена Порядком определения платы и ее предельных размеров за загрязнение окружающей природной среды, размещение отходов, другие виды вредного воздействия, утвержденным постановлением Правительства Российской Федерации от 28.08.1992 №632 [16], в соответствии с пунктом 1 которого указанный порядок распространяется на предприятия, учреждения, организации, осуществляющие любые виды деятельности, связанные с природопользованием и предусматривает взимание платы за вредное воздействие на окружающую среду.

Нормативы платы за вредное воздействие на окружающую среду установлены постановлением Правительства Российской Федерации от 12.06.2003 №344 «0 нормативах платы за выбросы в атмосферный воздух загрязняющих веществ стационарными и передвижными источниками, сбросы загрязняющих веществ в поверхностные и подземные водные объекты, размещение отходов производства и потребления» [17].

В случае если у должника возникла задолженность перед Российской Федерацией по обязательным платежам, вопрос о том, какой орган представляет интересы Российской Федерации в деле о банкротстве, урегулирован в законодательном порядке.

Всилупункта1ПостановленияПравительства Российской Федерации от 29.05.2004 №257 «Об обеспечении интересов Российской Федерации как кредитора в делах о банкротстве и в процедурах банкротства»и Постановления Правительства Российской Федерации от 30.09.2004 №506 «Об утверждении Положения о Федеральной налоговой службе» [18] уполномоченным органом по представлению в делах о банкротстве и в процедурах банкротства требований об уплате обязательных платежей и требований Российской Федерации по денежным обязательствам является ФНС России.

Таким образом, исключительно ФНС России вправе представлять требования об уплате обязательных платежей в деле о банкротстве.

Поэтому, учитывая особую функцию ФНС России в процедурах банкротства, публично-правовую цель института банкротства, Министерством экономического развития РФ письмом от 16.09.2009 №Д06-2677 даны разъяснения, что арбитражный суд вправе произвести замену в порядке процессуального правопреемства на ФНС России (по заявлению последней) в реестре требований кредиторов должника по требованиям Российской Федерации по денежным обязательствам в делах о банкротстве.

Указанные разъяснения возникли не случайно, поскольку зачастую требования относительно задолженности по платежам за негативное воздействие на окружающую среду в делах о банкротстве предъявляются органами Ростехнадзора, а не налоговыми органами, например, Постановление ФАС Северо-Западного округа от 30.03.2012 по делу №A44-355/2007.

Также встречаются ситуации, когда требования предъявляются вне рамок дела о банкротстве, например, Постановление ФАС Поволжского округа от 17.09.2009 по делу №А65-143/2009.

В других делах требования были изначально предъявлены налоговыми органами, например, Постановление Арбитражного суда Дальневосточного округа от 19.05.2015 № Ф03-1752/2015 по делу №А 24-4109/2012 (Определением Верховного Суда РФ от 02.09.2015 №303-ЭС14-3681 отказано в передаче дела №A24-4109/2012 в Судебную коллегию по эко- 


\section{Правовое регулирование налоговых отношений}

номическим спорам Верховного Суда РФ для пересмотра в порядке кассационного производства данного постановления), Постановление ФАС Уральского округа от 16.11.2011 №Ф09-7164/11 по делу №A34-1126(2в)/2010, Постановление ФАС Уральского округа от 27.12.2010 №Ф09-10988/10С4 по делу №A34-3992(11e)/2009, Постановление ФАС Центрального округа от 29.05.2014 по делу №A14-5068/2013. Следует отметить, в указанных делах судом применены сроки исковой давности, что отчасти связано с соблюдением порядка передачи информации между главным администратором соответствующих неналоговых поступлений бюджета к уполномоченному органу.

Крометого, в части взысканиязадолженности по текущим платежам полномочия Ростехнадзора сохраняются, например, Постановление ФАС Западно-Сибирского округа от 30.04.2013 по делу №A27-2403/2012, Постановление ФАС Западно-Сибирского округа от 23.01.2013 по делу №A27-6354/2012 (Определением ВАС РФ от 05.06.2013 №BAC-7097/13 отказано в передаче дела №A27-6354/2012 в Президиум ВАС РФ для пересмотра в порядке надзора данного постановления), Постановление ФАС Уральского округа от 16.11.2011 №Ф09-7164/11 по делу №A341126(2в)/2010. Равным образом, ответчиком по требованиям о возврате уплаченных денежных средств с нарушением очередности, установленной Законом о банкротстве выступают органы Ростехнадзора, например, Постановление Арбитражного суда Волго-Вятского округа от 04.09.2015 №Ф01-3493/2015 по делу №А8218074/2014 (Определением Верховного Суда РФ от 01.12.2015 №301-КГ15-15097 отказано в передаче дела №A82-18074/2014 в Судебную коллегию по экономическим спорам Верховного Суда РФ для пересмотра в порядке кассационного производства данного постановления).

Таким образом, представляется очевидным необходимость в совершенствовании механизмов передачи требований от компетентных органов государственной власти куполномоченному органу, представляющему интересы Российской Федерации в делах о банкротстве, что касается и иных органов, кроме Ростехнадзора, так как на практике выявлены два патогенных фактора: исполнение установленного порядка зачастую ведет к пропуску сроков давности для включения требований в реестр кредиторов; неисполнение же этого порядка формирует противоречивую и не многочисленную практику.

\section{Правовая природа задолженности по государственному контракту и порядок учета в делах о банкротстве}

Государственным контрактом, является договор, заключенный от имени РФ, субъекта РФ, государственным заказчиком для обеспечения государственных нужд (подпункт 8 статьи 3 Федерального закона от 05.04.2013 №44-Ф3 «0 контрактной системе в сфере закупок товаров, работ, услуг для обеспечения государственных и муниципальных нужд» [10]).

По своей природе государственный контракт представляет собой гражданско-правовой договор, поэтому защита нарушенных прав заказчика осуществляется в порядке характерном для гражданско-правового регулирования. При этом, в любом случае, с одной стороны данного правоотношения выступает казна, а значит защите подлежит публичный интерес.

В соответствии со статьей 125 Гражданского кодекса РФ [3], участие Российской Федерации и субъектов РФ в отношениях, регулируемых гражданским законодательством, осуществляется органами государственной власти в рамках их компетенций.

Права привлеченных к участию в деле о банкротстве органов, имеющих требования к должнику ограничены участием в судебных заседаниях, на что указывают суды (см. к примеру Постановление ФАС Дальневосточного округа от 17.09.2013 №Ф03-4443/2013 по делу №A59-4028/2012).

Вновь обращаясь к понятию «обязательный платеж», закрепленному в статье 2 Закона о банкротстве и Постановлению Правительства РФ №257, мы не увидим, что уполномоченный орган представляет в деле о банкротстве требования в основе которыхзадолженность по государственным контрактам. Вместе с этим статья 2 Закона о банкротстве раскрывает понятие «уполномоченный орган» через перечисление требований, представляемых таким органом, в том числе указаны требования Российской Федерации по денежным обязательствам. Конструкция этой нормы позволяет передать все права и обязанности 


\section{Налоги и налогообложение 10(148) • 2016}

заказчика по государственному контракту к ФНС РФ (см., например, Постановление Арбитражного суда Уральского округа от 07.04.2015 №Ф097174/12 по делу №А71-6486/2011).

Таким образом, следует отметить существенные различия при предъявлении требований в отношении денежной задолженности по государственному контракту и задолженности по обязательным платежам (налогам, сборам, государственным пошлинам).

В отношении задолженности по обязательным платежам, можно говорить о приоритете защиты интересов государства по отношению к интересам частных субъектов.

Конкурсный кредитор должен сначала получить судебное решение, тогда как налоговой службе достаточно самостоятельно вынести решение о взыскании задолженности.

Следовательно, налоговая служба получает возможность занять в реестре кредиторов более выгодное положение, чем конкурсные кредиторы.

В то же время, в отношении задолженности по государственному контракту РФ (субъект РФ) выступает в качестве равноправного субъекта, что обусловлено гражданско-правовой природой указанного договора, поэтому осуществление процедур происходит порядке сходном с процедурами, осуществляемыми частными хозяйствующими субъектами.

Следует заключить, что наделение уполномоченного органа компетенцией по представлению публичного интереса по государственным контрактам в делах о банкротстве, нельзя толковать таком образом чтобы соответствующее требование отождествлялось с категорией обязательный платёж.

\section{Залоговый статус уполномоченного органа как разновидность нетипичного требования в деле о банкротстве по налоговому обязательству.}

Ранее было неоднократно указано, что налоговые органы представляют в делах о банкротстве публичные интересы на основании положений Закона о банкротстве и руководствуясь Постановлением Правительства РФ от 29.05.2004 №257 «Об обеспечении интересов Российской Федерации как кредитора в деле о банкротстве и в процедурах, применяемых в деле о банкротстве».

При этом ни Закон о банкротстве, ни указанное положение не упоминает ситуации, при которой налоговой орган мог бы иметь обеспечение требований по налоговому обязательству в форме залога имущества должника.

Впервые о теоретической возможности залогового статуса уполномоченного органа по делам о банкротстве говорит С.А Ядрихинский [29]. До настоящего времени в отечественной судебной арбитражной практике не удалось встретить сколь либо относимого примера для такой ситуации. Это не означает невозможность ее существования или отсутствия нормативного регулирования для такого случая.

Определение «залога» содержится в пункте 3 статьи 73 Налогового кодекса РФ [4]: «При неисполнении налогоплательщиком или плательщиком сбора обязанности по уплате причитающихся сумм налога или сбора и соответствующих пеней налоговый орган осуществляет исполнение этой обязанности за счет стоимости заложенного имущества в порядке, установленном гражданским законодательством Российской Федерации».

Законодатель, определяя понятие налогового залога, упускает ключевой термин «преимущественное право» удовлетворения требований перед другими кредиторами. Вместе с тем само назначение налогового залога состоит в создании у налогового органа уверенности в том, что в случае неисполнения налогоплательщиком обязанности по уплате налогов он все же получит удовлетворение за счет стоимости заложенного имущества налогоплательщика или иного лица, причем первым среди всех остальных, т.е. преимущественно перед другими кредиторами. Иное приводило бы к абсурдной ситуации, поскольку налоговый орган в силу статьи 47 Налогового кодекса РФ и без оформления залога наделен правом взыскания налога за счет имущества налогоплательщика в случае неуплаты или неполной уплаты им налога в установленный срок.

Очевидно, что правило, устанавливающее привилегированное положение налогового органа - залогодержателя, приобретает особое значение на случай банкротства налогоплательщика по процедуре конкурсного производства, целью 


\section{Правовое регулирование налоговых отношений}

которой является соразмерное удовлетворение требований кредиторов (статья 2 Закона о банкротстве). При наступлении неплатежеспособности налогоплательщика и уменьшении объема его имущества за период отсрочки (рассрочки) меры принудительного взыскания могут оказаться неэффективными. При банкротстве такого налогоплательщика требования налоговых органов в силу положений пункт 4 статьи 134 Закона о банкротстве включаются в третью очередь реестра требований кредиторов и в подавляющем большинстве случаев при отсутствии залога просто списываются в связи с невозможностью их удовлетворения из-за недостатка имущества должника.

Наличие залога предоставляет налоговому органу статус залогового кредитора, при этом возбуждение процедуры банкротства налогоплательщика не влечет трансформации требований залогового кредитора в необеспеченное денежное обязательство - залогодержатель по-прежнему имеет право на удовлетворение из стоимости заложенной вещи, но только по правилам процедуры банкротства.

Привилегия залогового кредитора перед остальными кредиторами заключается в гарантированном получении 70\% средств, вырученных от реализации предмета залога. Однако эта сумма не может превышать суммы основной задолженности по обеспеченному залогом обязательству и причитающихся процентов (п. 1 ст. 138 Закона о банкротстве, п. 15 Постановления Пленума Высшего Арбитражного Суда РФ от 23 июля 2009 г. №58 «0 некоторых вопросах, связанных с удовлетворением требований залогодержателя при банкротстве залогодателя»). Институт налогового залога, таким образом, служит гарантией исполнения налоговой обязанности налогоплательщика.

Сфера обеспечительного действия налогового залога в первоначальной редакции Налогового кодекса РФ была ограничена случаем изменения сроков исполнения обязанностей по уплате налогов и сборов. Однако Федеральным законом от 27.07.2010 №229-Ф3 «О внесении изменений в часть первую и часть вторую Налогового кодекса Российской Федерации и некоторые другие законодательные акты Российской Федерации, а также о признании утратившими силу отдельных законодательных актов (положений законодательных актов) Российской Федерации в связи с урегулированием задолженности по уплате налогов, сборов, пеней и штрафов и некоторых иных вопросов налогового администрирования» [11] (п. 24 ст. 1) редакция п. 1 ст. 73 НК РФ была изменена и теперь налоговый залог, помимо случая изменения сроков исполнения обязанностей по уплате налогов, может применяться в любых других случаях, предусмотренных Налоговым кодексом РФ.

Таким случаем с 24 августа 2013 года является норма статьи 77 Налогового кодекса РФ, внесенная Федеральным законом от 23.07.2013 №248-Ф3 «О внесении изменений в части первую и вторую Налогового кодекса Российской Федерации и некоторые другие законодательные акты Российской Федерации, а также о признании утратившими силу отдельных положений законодательных актов Российской Федерации» [12], дополненная пунктом 12.1. В соответствии с ним по просьбе налогоплательщика-организации арест имущества может быть заменен на залог имущества в порядке статьи 73 Налогового кодекса РФ. При этом решение об аресте имущества отменяется (пункт 13 статьи 77 Налогового кодекса РФ).

Следовательно, помимо полномочий прямо предоставленных налоговому органу Законом о банкротстве и Постановлением Правительства РФ №257, налоговый орган приобретает дополнительные права об определении порядка, условий и сроков продажи заложенного имущества, право ходатайствовать перед судом об утверждении начальной продажной стоимости заложенного имущества, а также право оставить предмет залога за собой в счет погашения задолженности по обязательным платежам, в случае не реализации имущества должника в установленном порядке.

Безусловно, залог не является единственным способом обеспечения исполнения обязательств налогоплательщиком-должником, и опыт других стран свидетельствует возможном применении к должникам процедур, обеспечивающих исполнения налоговой обязанности с определенным приоритетом по сравнению с частными кредиторами: опубликование сведений о неисполнении публично-правовой обязанности по уплате 


\section{Налоги и налогообложение 10(148) • 2016}

налогов (Франция, Дания), ограничение права собственности на имущество должника, включая его конфискацию (Италия), отстранение руководителя должника - дисквалификация (Великобритания) и другие [28].

Однако мировая практика признает защиту прав государства, обеспеченных залогом, по делам о банкротстве на том же, а иной раз и большем уровне по сравнению с частными кре- диторами, чьи права также обеспечены залогом имущества должника. Например, соглашения о залоге имущества должника в обеспечение требований по уплате задолженности по налогам и иным публичным сборам предусмотрено по законодательству Китая [33], Канады [36], Соединенных Штатов Америки [34], Германии [35], Франции [32], Мексики [30], Австралии [31] и других стран.

\section{Библиография}

1. О Конституционном Суде Российской Федерации: Федерального конституционного закона от 21.07.1994 №1-ФКЗ. Российская газета, №138-139, 23.07.1994.

2. Бюджетный кодекс Российской Федерации. СЗ РФ. 03.08.1998, №31, ст. 3823.

3. Гражданский кодекс Российской Федерации (часть первая) от 30.11.1994 №51-ФЗ. СЗ РФ, 05.12.1994, №32, ст. 3301.

4. Налоговый кодекс Российской Федерации (часть первая) от 31.07.1998 №146-Ф3. Российская газета, №148-149, 06.08.1998.

5. Таможенный кодекс Таможенного союза (приложение к Договору о Таможенном кодексе Таможенного союза, принятому Решением Межгосударственного Совета ЕврАзЭС на уровне глав государств от 27.11.2009 №17). СЗ РФ. 13.12.2010, №50, ст. 6615.

6. О несостоятельности (банкротстве): Федеральный закон от 26.10.2002 №127-ФЗ (ред. от 13.07.2015) // СЗ РФ. 28.10.2002. №43. ст. 4190.

7. О несостоятельности (банкротстве): Федеральный закон от 08.01.1998 №6-ФЗ // СЗ РФ, 12.01.1998, №2, ст. 222.

8. Об исполнительном производстве: Федеральный закон от 02.10.2007 №229-ФЗ. СЗ РФ. 08.10.2007. №41. ст. 4849.

9. Об охране окружающей среды: Федеральный закон от 10.01.2002 №7-Ф3. Российская газета, №6, 12.01.2002.

10. О контрактной системе в сфере закупок товаров, работ, услуг для обеспечения государственных и муниципальных нужд: Федеральный закон от 05.04.2013 №44-ФЗ. СЗ РФ. 08.04.2013, №14, ст. 1652.

11. О внесении изменений в часть первую и часть в торую Налогового кодекса Российской Федерации и некоторые другие законодательные акты Российской Федерации, а также о признании утратившими силу отдельных законодательных актов (положений законодательных актов) Российской Федерации в связи сурегулированием задолженности по уплате налогов, сборов, пеней и штрафов и некоторых иных вопросов налогового администрирования: Федеральный закон от 27.07.2010 №229-ФЗ. Российская газета, №169, 02.08.2010.

12. О внесении изменений в части первую и вторую Налогового кодекса Российской Федерации и некоторые другие законодательные акты Российской Федерации, а также о признании утратившими силу отдельных положений законодательных актов Российской Федерации: Федеральный от 23.07.2013 №248-Ф3. Российская газета, №163, 26.07.2013.

13. О введении в действие части первой Налогового кодекса Российской Федерации: Федеральный закон от 31.07.1998 №147-ФЗ (ред. от 29.07.2004) // СЗ РФ, 03.08.1998, №31, ст. 3825.

14. Постановление Правительства РФ от 29.05.2004 №257 (ред. от 20.01.2016) «Об обеспечении интересов Российской Федерации как кредитора в деле о банкротстве и в процедурах, применяемых в деле о банкротстве» (вместе с «Положением о порядке предъявления требований по обязатель- 


\section{Правовое регулирование налоговых отношений}

ствам перед Российской Федерацией в деле о банкротстве и в процедурах, применяемых в деле о банкротстве») // Российская газета, №113, 01.06.2004.

15. Постановление Правительства Российской Федерации от 13.09.2010 №717 «0 внесении изменений в некоторые Постановления Правительства Российской Федерации по вопросам полномочий Министерства природных ресурсов и экологии Российской Федерации, Федеральной службы по надзору в сфере природопользования и Федеральной службы по экологическому, технологическому и атомному надзору» // СЗ РФ, 20.09.2010, №38, ст. 4835.

16. Постановление Правительства Российской Федерации от 28.08.1992 №632 (ред. от 26.12.2013) «Об утверждении Порядка определения платы и ее предельных размеров за загрязнение окружающей природной среды, размещение отходов, другие виды вредного воздействия» // Собрание актов Президента и Правительства РФ, 07.09.1992, №10, ст. 726.

17. Постановление Правительства РФ от 12.06.2003 №344 (ред. от 24.12.2014) «0 нормативах платы за выбросы в атмосферный воздух загрязняющих веществ стационарными и передвижными источниками, сбросы загрязняющих веществ в поверхностные и подземные водные объекты, в том числе через централизованные системы водоотведения, размещение отходов производства и потребления» // Российская газета, №120, 21.06.2003.

18. Постановление Правительства РФ от 30.09.2004 №506 (ред. от 05.02.2016) «Об утверждении Положения о Федеральной налоговой службе» // СЗ РФ, 04.10.2004, №40, ст. 3961.

19. Постановление Конституционного Суда РФ от 30.07.2001 №13-П «По делу о проверке конституционности положений подпункта 7 пункта 1 статьи 7, пункта 1 статьи 77 и пункта 1 статьи 81 Федерального закона «Об исполнительном производстве» в связи с запросами Арбитражного суда Воронежской области, Арбитражного суда Саратовской области и жалобой открытого акционерного общества «Разрез «Изыхский» // СЗ РФ, 06.08.2001, №32, ст. 3412.

20. Определение Конституционного Суда РФ от 10.12.2002 №284-О «По запросу Правительства Российской Федерации о проверке конституционности Постановления Правительства Российской Федерации «Об утверждении Порядка определения платы и ее предельных размеров за загрязнение окружающей природной среды, размещение отходов, другие виды вредного воздействия» и статьи 7 Федерального закона «О введении в действие части первой Налогового кодекса Российской Федерации» // Российская газета, №241, 25.12.2002.

21. Борисов А.Н. Комментарий к Федеральному закону от 26 октября 2002 г. №127-Ф3 «0 несостоятельности (банкротстве)» (постатейный). 2-е изд., перераб. и доп. // СПС КонсультантПлюс. 2014.

22. Бунина А.Ю. Администраторам платы за негативное воздействие // Бюджетный учет. №11. 2008. C. 43.

23. Викторов С. А. О месте обязательного социального страхования в современной системе российского права // Тематический выпуск: Учетная политика предприятия для целей налогообложения на 2008 год. Брызгалин А.В., Берник В.Р., Головкин А.Н., Викторов С.А., Казанцев М.Ф., Прудиус Е.В. // Налоги и финансовое право, 2007, №11. 256 с.

24. Деревягина Л. А. Взыскание исполнительского сбора как обязательного платежа в рамках дела о банкротстве // Арбитражная практика. 2009. №3.-C. 77-80.-ISSN 1608-6732.

25. Иголкина К. Н. Взыскание исполнительского сбора // дисс. канд.юрид.наук: 12.00.14. М., 2013. С. 167.

26. Извеков С. С. Отдельные вопросы правового режима исполнения налоговой обязанности по уплате НДС при банкротстве налогоплательщика // Налоги и налогообложение. - 2016.-№5.-С.372-386. DOI: 10.7256/1812-8688.2016.5.17958.

27. Извеков С. С. Отдельные аспекты налогообложения налогом на доходы физических лиц при банкротстве налогового агента // Налоги и финансовое право. - 2016.-№5.-С. 126 - 133.

28. Солдатенков В. Ю. О взыскании налоговой задолженности в странах Европы. Налоговая политика и практика.-2012.-№12.-C. 72-74.-ISSN 2071-5250. 


\section{Налоги и налогообложение 10(148) • 2016}

29. Ядрихинский С.А. Механизм обеспечения исполнения обязанности по уплате налогов: проблемы теории и практики / отв. ред. Е.Ю. Грачева. М.: НОРМА, ИНФРА-М, 2015. 144 с.

30. Carlos Sánchez-Mejorada, Remarks at The American Law Institute, Seventy-Seventh Annual Meeting, Washington, D.C. (May 16, 2000).

31. Douglas G. Baird, The Elements of Bankruptcy 86 (1992).

32. David Lacey, Preferential Claims of Government in English Insolvency Proceedings, In Corporate Insolvency And Rescue: The International Dimension., at 222.

33. The Enterprise Bankruptcy Law of the People's Republic of China, adopted at the 23rd Meeting of the Standing Committee of the Tenth National People's Congress of the People's Republic of China on August 27, 2006; URL: http://www.china.org.cn/china/2011-02/11/content_21898381.htm (07.07.2016).

34. In re Lyons, 148 B.R. 88, 94 (Bankr. D. D.C. 1992), contra In re Street, 165 B.R. 408, 409-10 (Bankr. D. Md. 1994). VA. Code $\S 55-142.1$ (Michie 1995). case McDermott v. United States, 507 U.S. 447, 449 (1993) (quoting United States v. New Britain, 347 U.S. 81, 85 (1954)).

35. Klaus Wimmer, The New German Insovency Statute: Part 1, 29 B.C.D. A3, A8 (July 1996). Manfred Balz, The European Convention on Insolvency Proceedings, 70 AM. BANKR. L.J. 485, 491 n.23 (1996).

36. Jacob S. Ziegel, Canada's Phased-In Bankruptcy Law Reform, 70 AM. BANKR. L.J. 383, 409 (1996).

\section{References (transliterated)}

1. O Konstitutsionnom Sude Rossiiskoi Federatsii: Federal'nogo konstitutsionnogo zakona ot 21.07.1994 №1-FKZ. Rossiiskaya gazeta, №138-139, 23.07.1994.

2. Byudzhetnyi kodeks Rossiiskoi Federatsii. SZ RF. 03.08.1998, №31, st. 3823.

3. Grazhdanskii kodeks Rossiiskoi Federatsii (chast' pervaya) ot 30.11.1994 №51-FZ. SZ RF, 05.12.1994, №32, st. 3301.

4. Nalogovyi kodeks Rossiiskoi Federatsii (chast' pervaya) ot 31.07.1998 №146-FZ. Rossiiskaya gazeta, №148-149, 06.08.1998.

5. Tamozhennyi kodeks Tamozhennogo soyuza (prilozhenie k Dogovoru o Tamozhennom kodekse Tamozhennogo soyuza, prinyatomu Resheniem Mezhgosudarstvennogo Soveta EvrAzES na urovne glav gosudarstv ot 27.11.2009 №17). SZ RF. 13.12.2010, №50, st. 6615.

6. O nesostoyatel'nosti (bankrotstve): Federal'nyi zakon ot 26.10.2002 №127-FZ (red. ot 13.07.2015) // SZ RF. 28.10.2002. №43. st. 4190.

7. O nesostoyatel'nosti (bankrotstve): Federal'nyi zakon ot 08.01.1998 №6-FZ // SZ RF, 12.01.1998, №2, st. 222.

8. Ob ispolnitel'nom proizvodstve: Federal'nyi zakon ot 02.10.2007 №229-FZ. SZ RF. 08.10.2007. №41. st. 4849.

9. Ob okhrane okruzhayushchei sredy: Federal'nyi zakon ot 10.01.2002 №7-FZ. Rossiiskaya gazeta, №6, 12.01.2002.

10. O kontraktnoi sisteme v sfere zakupok tovarov, rabot, uslug dlya obespecheniya gosudarstvennykh i munitsipal'nykh nuzhd: Federal'nyi zakon ot 05.04.2013 №44-FZ. SZ RF. 08.04.2013, №14, st. 1652.

11. O vnesenii izmenenii $v$ chast' pervuyu i chast' vtoruyu Nalogovogo kodeksa Rossiiskoi Federatsii i nekotorye drugie zakonodatel'nye akty Rossiiskoi Federatsii, a takzhe o priznanii utrativshimi silu otdel'nykh zakonodatel'nykh aktov (polozhenii zakonodatel'nykh aktov) Rossiiskoi Federatsii v svyazi s uregulirovaniem zadolzhennosti po uplate nalogov, sborov, penei i shtrafov i nekotorykh inykh voprosov nalogovogo administrirovaniya: Federal'nyi zakon ot 27.07.2010 №229-FZ. Rossiiskaya gazeta, №169, 02.08.2010.

12. O vnesenii izmenenii v chasti pervuyu i vtoruyu Nalogovogo kodeksa Rossiiskoi Federatsii i nekotorye drugie zakonodatel'nye akty Rossiiskoi Federatsii, a takzhe o priznanii utrativshimi silu otdel'nykh polozhenii zakonodatel'nykh aktov Rossiiskoi Federatsii: Federal'nyi ot 23.07.2013 №248-FZ. Rossiiskaya gazeta, №163, 26.07.2013. 


\section{Правовое регулирование налоговых отношений}

13. O vvedenii v deistvie chasti pervoi Nalogovogo kodeksa Rossiiskoi Federatsii: Federal'nyi zakon ot 31.07.1998 №147-FZ (red. ot 29.07.2004) // SZ RF, 03.08.1998, №31, st. 3825.

14. Postanovlenie Pravitel'stva RF ot 29.05.2004 №257 (red. ot 20.01.2016) «Ob obespechenii interesov Rossiiskoi Federatsii kak kreditora v dele o bankrotstve i v protsedurakh, primenyaemykh v dele o bankrotstve» (vmeste s «Polozheniem o poryadke pred"yavleniya trebovanii po obyazatel'stvam pered Rossiiskoi Federatsiei v dele o bankrotstve i v protsedurakh, primenyaemykh v dele o bankrotstve») // Rossiiskaya gazeta, №113, 01.06.2004.

15. Postanovlenie Pravitel'stva Rossiiskoi Federatsii ot 13.09.2010 №717 «0 vnesenii izmenenii v nekotorye Postanovleniya Pravitel'stva Rossiiskoi Federatsii po voprosam polnomochii Ministerstva prirodnykh resursov i ekologii Rossiiskoi Federatsii, Federal'noi sluzhby po nadzoru v sfere prirodopol'zovaniya i Federal'noi sluzhby po ekologicheskomu, tekhnologicheskomu i atomnomu nadzoru» // SZ RF, 20.09.2010, №38, st. 4835.

16. Postanovlenie Pravitel'stva Rossiiskoi Federatsii ot 28.08.1992 №632 (red. ot 26.12.2013) «Ob utverzhdenii Poryadka opredeleniya platy i ee predel'nykh razmerov za zagryaznenie okruzhayushchei prirodnoi sredy, razmeshchenie otkhodov, drugie vidy vrednogo vozdeistviya» // Sobranie aktov Prezidenta i Pravitel’stva RF, 07.09.1992, №10, st. 726.

17. Postanovlenie Pravitel’stva RF ot 12.06.2003 №344 (red. ot 24.12.2014) «0 normativakh platy za vybrosy $\mathrm{v}$ atmosfernyi vozdukh zagryaznyayu shchikh veshchestv statsionarnymi i peredvizhnymi istochnikami, sbrosy zagryaznyayushchikh veshchestv v poverkhnostnye i podzemnye vodnye ob"ekty, $v$ tom chisle cherez tsentralizovannye sistemy vodootvedeniya, razmeshchenie otkhodov proizvodstva i potrebleniya» // Rossiiskaya gazeta, №120, 21.06.2003.

18. Postanovlenie Pravitel'stva RF ot 30.09.2004 №506 (red. ot 05.02.2016) «Ob utverzhdenii Polozheniya o Federal'noi nalogovoi sluzhbe» // SZ RF, 04.10.2004, №40, st. 3961.

19. Postanovlenie Konstitutsionnogo Suda RF ot 30.07.2001 №13-P «Po delu o proverke konstitutsionnosti polozhenii podpunkta 7 punkta 1 stat'i 7, punkta 1 stat'i 77 i punkta 1 stat'i 81 Federal'nogo zakona «Ob ispolnitel'nom proizvodstve» v svyazi s zaprosami Arbitrazhnogo suda Voronezhskoi oblasti, Arbitrazhnogo suda Saratovskoi oblasti i zhaloboi otkrytogo aktsionernogo obshchestva «Razrez «Izykhskii» // SZ RF, 06.08.2001, №32, st. 3412.

20. Opredelenie Konstitutsionnogo Suda RF ot 10.12.2002 №284-O «Po zaprosu Pravitel'stva Rossiiskoi Federatsii o proverke konstitutsionnosti Postanovleniya Pravitel'stva Rossiiskoi Federatsii «Ob utverzhdenii Poryadka opredeleniya platy i ee predel'nykh razmerov za zagryaznenie okruzhayushchei prirodnoi sredy, razmeshchenie otkhodov, drugie vidy vrednogo vozdeistviya» i stat'i 7 Federal'nogo zakona «0 vvedenii v deistvie chasti pervoi Nalogovogo kodeksa Rossiiskoi Federatsii» // Rossiiskaya gazeta, №241, 25.12.2002.

21. Borisov A.N. Kommentarii k Federal'nomu zakonu ot 26 oktyabrya 2002 g. №127-FZ «0 nesostoyatel'nosti (bankrotstve)» (postateinyi). 2-e izd., pererab. i dop. // SPS Konsul'tantPlyus. 2014.

22. Bunina A.Yu. Administratoram platy za negativnoe vozdeistvie // Byudzhetnyi uchet. №11. 2008. C. 43.

23. Viktorov S. A. O meste obyazatel'nogo sotsial'nogo strakhovaniya v sovremennoi sisteme rossiiskogo prava // Tematicheskii vypusk: Uchetnaya politika predpriyatiya dlya tselei nalogooblozheniya na 2008 god. Bryzgalin A.V., Bernik V.R., Golovkin A.N., Viktorov S.A., Kazantsev M.F., Prudius E.V. // Nalogi i finansovoe pravo, 2007, №11. $256 \mathrm{~s}$.

24. Derevyagina L. A. Vzyskanie ispolnitel'skogo sbora kak obyazatel'nogo platezha v ramkakh dela o bankrotstve // Arbitrazhnaya praktika. 2009. №3.-S. 77-80.-ISSN 1608-6732.

25. Igolkina K. N. Vzyskanie ispolnitel'skogo sbora // diss. kand.yurid.nauk: 12.00.14. M., 2013. S. 167.

26. Izvekov S. S. Otdel'nye voprosy pravovogo rezhima ispolneniya nalogovoi obyazannosti po uplate NDS pri bankrotstve nalogoplatel'shchika // Nalogi i nalogooblozhenie. - 2016.-№5.-S.372-386. DOI: 10.7256/1812-8688.2016.5.17958. 


\section{Налоги и налогообложение 10(148) • 2016}

27. Izvekov S. S. Otdel'nye aspekty nalogooblozheniya nalogom na dokhody fizicheskikh lits pri bankrotstve nalogovogo agenta // Nalogi i finansovoe pravo. - 2016.-№5.-S. 126 - 133.

28. Soldatenkov V. Yu. O vzyskanii nalogovoi zadolzhennosti v stranakh Evropy. Nalogovaya politika i praktika.-2012.-№12.-S. 72-74.-ISSN 2071-5250.

29. Yadrikhinskii S.A. Mekhanizm obespecheniya ispolneniya obyazannosti po uplate nalogov: problemy teorii i praktiki / otv. red. E.Yu. Gracheva. M.: NORMA, INFRA-M, 2015. 144 s.

30. Carlos Sánchez-Mejorada, Remarks at The American Law Institute, Seventy-Seventh Annual Meeting, Washington, D.C. (May 16, 2000).

31. Douglas G. Baird, The Elements of Bankruptcy 86 (1992).

32. David Lacey, Preferential Claims of Government in English Insolvency Proceedings, In Corporate Insolvency And Rescue: The International Dimension., at 222.

33. The Enterprise Bankruptcy Law of the People's Republic of China, adopted at the 23rd Meeting of the Standing Committee of the Tenth National People's Congress of the People's Republic of China on August 27, 2006; URL: http://www.china.org.cn/china/2011-02/11/content_21898381.htm (07.07.2016).

34. In re Lyons, 148 B.R. 88, 94 (Bankr. D. D.C. 1992), contra In re Street, 165 B.R. 408, 409-10 (Bankr. D. Md. 1994). VA. Code § 55-142.1 (Michie 1995). case McDermott v. United States, 507 U.S. 447, 449 (1993) (quoting United States v. New Britain, 347 U.S. 81, 85 (1954)).

35. Klaus Wimmer, The New German Insovency Statute: Part 1, 29 B.C.D. A3, A8 (July 1996). Manfred Balz, The European Convention on Insolvency Proceedings, 70 AM. BANKR. L.J. 485, 491 n.23 (1996).

36. Jacob S. Ziegel, Canada's Phased-In Bankruptcy Law Reform, 70 AM. BANKR. L.J. 383, 409 (1996). 